\title{
Measuring the Accuracy of Bus Rapid Transit Forecasts
}

John Perry

\begin{abstract}
The research of Dr. Bent Flyvbjerg in the 1990s and early 2000s showed that urban rail projects often cost more than estimated and carried fewer riders than projected, a troubling trend suggesting that the forecasts for urban rail projects were too optimistic in terms of cost and ridership. Inspired by that research, this analysis seeks to extend that framework to analyze Bus Rapid Transit (BRT). A study of forecast vs. actual costs and ridership was conducted for $19 B R T$ projects in the United States. From this, it was found that the cost projections for these projects tended to be quite accurate, but ridership projections tended to be quite inaccurate and showed a clear tendency towards an optimism bias. As BRT becomes a more common choice for rapid transit investment in the US, this analysis suggests that current ridership forecasting methods still leave much to be desired.
\end{abstract}

Keywords: Forecasting, inaccuracy, bus rapid transit, BRT

\section{Introduction}

When it was published, the research of Dr. Bent Flyvbjerg illustrated a consistent inaccuracy of urban rail transit project forecasts in regards to cost and ridership. Compared to road and highway projects, which showed a relatively even distribution in terms of inaccuracy between those projects that overestimated and underestimated the costs and usership of the finished project, urban rail projects were consistently projected under the actual cost and above the actual ridership. Based on these findings, Flyvbjerg called for greater accountability over forecasts of large-scale transportation projects (Flyvbjerg et al. 2005).

In the past several years, BRT has become an increasingly common choice for city and local governments when investing in rapid transit. At a time when many transit agencies are experiencing budget cuts and service reductions, the relatively low capital costs of BRT make it an attractive option for transit agencies looking to expand their rapid transit services. In 2014 alone, there were 24 BRT projects completed or under construction in the US (Freemark 2014). 
Compared to the megaprojects and urban rail projects that Flyvbjerg studied, these BRT projects seem relatively inexpensive. But for many small and mid-size American cities, a BRT project may represent one of the most significant investments in public transportation in that community's history. As such, it is just as important that planners strive for accuracy when projecting cost and ridership.

Much has been written about the characteristics of BRT and the current state of BRT development, and there is a substantial body of research regarding the economic and development impacts of a BRT system, but there is much less research regarding BRT ridership and cost forecasts. Also, although there is a large body of work on travel forecasts, most obviously Flyvbjerg's research, most of it pertains specifically to freeway or urban rail megaprojects. Given the growing interest in BRT systems among local governments and transportation professionals, this is a gap in the current research.

\section{Literature Review}

There is a large and growing body of research on BRT, most of which generally fits into one of three categories: the basic characteristics of BRT, the current state of BRT development, and the economic and development impacts of BRT. In each of these categories, there is much research comparing the characteristics and impacts of BRT to those of other forms of rapid transit, particularly light rail.

A substantial amount of work has been written about the service characteristics of urban transportation modes, including BRT, and this work offers useful parameters for defining BRT systems and the opportunities for its development. This research attempted to define the level of service characteristics at which point a system can be considered "bus rapid transit" and found that BRT is growing in popularity due to its cost effectiveness and the fact that it can be adapted for use in conventional bus systems (Vuchic 1992; Jarzab et al. 2002; Levinson et al. 2002). Additionally, the Institute for Transportation Policy (ITDP), a non-profit organization that provides technical assistance on public transportation projects and advocates for BRT development, has developed a ranking system for comparing BRT systems and determining whether a system meets their standards for what can be considered "true" BRT (Weinstock et al. 2011). This research proved useful for understanding the characteristics of BRT and what could, even nominally, be considered as such.

Flyvbjerg's work served as a model for this work. Building on a body of work from the 1990s and early 2000s, his research examined the accuracy of cost and ridership forecasts for large transportation projects, particularly urban rail and road projects, and found that urban rail projects frequently exhibited large cost overruns and typically presented very optimistic ridership forecasts compared with road projects, due, in part, to poor forecasting methods and to biases on the part of the forecasters to promote rail projects (Flyvbjerg et al. 2005); however, none of Flyvbjerg's work dealt with bus transit projects. More recently, the work of Robert Bain has contributed significantly to this field of research, calling to attention widespread inaccuracy and optimism bias in traffic forecasts for toll road projects (Bain 2009). 
Another resource dealing with cost and ridership projections was a series of before-andafter studies conducted by the Federal Transit Administration (FTA) regarding transit projects that have received New Starts funding (FTA 2006-2016). These studies also document a tendency to underestimate final construction costs, with the accuracy of ridership projections varying widely. However, these studies deal mostly with urban and commuter rail projects, with only a couple of bus transit projects included. This general lack of attention towards cost and ridership projections for BRT projects is a gap in the current literature.

\section{Methodology}

Funding and ridership information is collected by FTA, but most of this information deals with transit agencies as a whole rather than individual infrastructure projects. In cases in which cost and ridership estimates from the transit agency operating the BRT system were unavailable, the necessary information was obtained from media articles and government reports. BRT systems in operation in the US for which reliable and comparable data were not available are not included in this analysis. In total, 19 projects were included in the final analysis.

The methodologies Flyvbjerg employed in his research served as a guide for this research. Many projects go through multiple forecasts that change as a project moves forward through the design and construction phases. In his research, Flyvbjerg used the project forecasts from the time of the decision to build, arguing that this is the information available to decisionmakers when they agree to move forward on a project and, thus, are the most influential in determining the worthiness of a project. These figures were then compared to the actual figures from the completion of the project to determine their accuracy (Flyvbjerg et al. 2005). This is, in brief, what was attempted in this analysis, using figures as close to the time of the decision to build as were available.

Given the small number of what the ITDP would refer to as "true" BRT systems in the US-that is, systems that have all or nearly all of the features of BRT, such as dedicated lanes, pre-boarding payment, limited stops, and branded service-this analysis also includes some so-called "BRT-lite" systems (those with only a few of the features of BRT) and busway projects to produce a statistically-significant sample of BRT projects. Although not all of these systems fall into what the ITDP would deem "true" BRT, they do all represent significant investments in public transportation for each of the cities included here, so their value for an analysis of BRT cost and ridership projections should not be dismissed.

\section{Individual Case Studies}

Note that all dollar values are adjusted to values in the year of expenditure. 


\section{Cleveland, Ohio}

The HealthLine is a 7.1-mile BRT line operated by the Greater Cleveland Regional Transit Authority (GCRTA). It opened in October 2008 and features exclusive bus lanes and median stations for 4.4 miles of the line, with the remaining 2.7 miles using mixed-traffic curb lanes and sidewalk stops. The HealthLine also uses distinctive station structures, off-board fare equipment, signal priority for vehicles at traffic intersections (FTA 2012). ITDP gave the HealthLine the highest ranking of any BRT system in the US, indicating that they consider it the most complete example of BRT in the US (Weinstock et al. 2011).

Projected capital costs for the HealthLine were $\$ 273.4$ million according to a 1995 estimate; however, further revisions set estimates ranging from $\$ 248.2$ million to $\$ 317.4$ million. Due to cost-effectiveness requirements to receive federal funding, GCRTA trimmed costs for design elements and vehicle procurement and used management tools to monitor the project budget (GCRTA 2012). In the end, the actual capital costs were $\$ 197.2$ million (GCRTA 2012).

Projected ridership for the HealthLine initially was 21,100 average weekday trips, although this later was revised to 13,500 (FTA, 2012). Actual ridership on the line was 14,300 average weekday trips as of 2012, well below the initial projection. At the time of opening, Cleveland was in the midst of a substantial contraction of the regional economy and a subsequent drop in system-wide transit ridership, which fell by $22 \%$ between 2007 and 2010 (FTA 2012). This may go some way towards explaining why the actual ridership was so far below early estimates.

\section{El Paso, Texas}

The Brio Mesa Corridor is an 8.6-mile BRT-lite line operated by Sun Metro. Completed in October 2014, the Mesa Corridor route was the first of four planned Brio routes scheduled to open within the coming years and is currently the only rapid transit service in El Paso (Sun Metro 2014). The line features branded and landscaped stations, pre-boarding fare payment, and traffic signal priority.

Projected capital costs for the line were $\$ 27.08$ million (FTA 2010), with actual capital costs reported at $\$ 27.1$ million (Sun Metro 2014). Projected ridership initially was 11,900 average weekday boardings within the opening year (FTA 2010), but this was revised to around 3,000 riders per day prior to Brio's opening. Actual ridership was below even this lowered revision, with 52,000 average monthly boardings as of July 2016 (Wilcox 2016), an average of about 2,000 riders each operating day (Brio currently operates only six days per week).

\section{Escondido, California}

The Breeze Rapid is a 6-mile BRT-lite service operated by the North County Transit District (NCTD). Service began in June 2011 and features queue jump lanes at select intersections, traffic signal priority, bus station improvements, and branded service. 
Projected capital costs for the system were $\$ 2.79$ million, according to a NCTD 2006 concept study, with actual capital costs at $\$ 4.21$ million. The Breeze Rapid came in over budget due, in large part, to revised plans for one intersection, at which a proposed queue jump lane was extended that required widening of the roadway for a full block to accommodate the new lane. ${ }^{1}$

No formal ridership projection for the service was conducted; as the first instance of a rapid bus service in the region, the San Diego Association of Governments (SANDAG), the regional planning agency for San Diego County, treated it as a technology and concept demonstration that upgraded an existing local bus route rather than a project to significantly boost ridership. ${ }^{2}$

\section{Eugene, Oregon}

The Emerald Express (EmX) is a BRT system operated by the Lane Transit District (LTD). An initial 4-mile segment opened in January 2007, with a 7.8-mile extension opening in January 2011. The EmX uses dedicated bus lanes for nearly $60 \%$ of its route, with a traffic signal priority system and branded stations with raised platforms, pre-boarding fare payment, and real-time bus arrival signs. The system has been noted as a BRT success story by the ITDP (Weinstock et al. 2011), constructed within budget and with ridership exceeding stated expectations.

Projected capital costs were $\$ 24.6$ million for the initial segment and $\$ 43.1$ million for the extension. These proved to be reasonably accurate, with actual capital costs being $\$ 24.6$ million for the initial segment and $\$ 41.3$ million for the extension. ${ }^{3}$

It was projected that the served corridor would see an increase of $40 \%$ over the first 20 years of service. In fact, there was a ridership increase of $63 \%$ in the corridor over the first year of service and 122\% over the first four years. The 2011 extension was projected to increase ridership along the $\mathrm{EmX}$ line by 3,700 additional weekday boardings. After completion, the extension reached $80 \%$ of this projection within one year and exceeded it in the second year of service. Currently, weekday ridership averages $10,000+$ during the school year and exceeds 11,000 in some months, $135 \%$ of the estimate predicted for the line after completion of the extension. ${ }^{4}$

\section{Fort Collins, Colorado}

MAX is a 5-mile BRT line operated by Transfort. The line opened in May 2014 and features a dedicated transit-only busway for most of the route, branded service, preboarding fare payment, and platform-level boarding at all stations along the route.

\footnotetext{
${ }^{1}$ Information obtained through personal communication with D. Veeh, December 30, 2013.

${ }^{2}$ Ibid.

${ }^{3}$ Information obtained through personal communication with A. Vobora, February 8, 2014.

${ }^{4}$ lbid.
} 
Projected capital costs for the system were $\$ 81.98$ million (FTA 2009), with actual capital costs coming in at $\$ 86.83$ million (Duggan 2014). Projected ridership was 3,900 average weekday boardings (FTA, 2009). MAX managed to exceed this figure after its first year of service, with 4,680 average daily boardings in September 2015 (de la Rosa 2015).

\section{Grand Rapids, Michigan}

The Silver Line is a 9.8-mile BRT-lite service operated by the Interurban Transit Partnership. The line opened in August 2014 and features stations with a sidewalk snowmelt system, next bus signage, platform-level boarding, pre-boarding fare payment, and designated bus-only travel lanes along portions of the route during peak weekday travel periods.

Projected capital costs were $\$ 37$ million (FTA 2010), with actual capital costs being $\$ 40$ million (Krietz 2014). Projected ridership was 7,200 average weekday boardings in the first year (FTA 2010). Actual ridership fell well below this mark, with only 2,300 average weekday boardings as of March 2016 (Khut 2016).

\section{Kansas City, Missouri}

The Troost Avenue MAX is a 13-mile BRT-lite service operated by the Kansas City Area Transportation Authority (KCATA). Following the successful implementation of the MAX bus rapid transit line along Main Street in July 2005, KCATA began pursuing implementation of a second line along Troost Avenue, roughly one mile west of and parallel to the existing Main Street MAX line. As of 2007, the Main Street MAX line had resulted in a $20 \%$ growth in ridership along the Main Street corridor, and planners expected similar results from the new Troost Avenue line (FTA 2007). The Troost Avenue MAX opened in January 2011 and features dedicated bus lanes, traffic signal prioritization, branded buses and stations.

Projected capital costs for the line were $\$ 30.73$ million (FTA 2007), with actual capital costs at $\$ 30.6$ million (KCATA 2010). Projected ridership was 9,000 average weekday boardings after the first year of service (FTA 2007). This proved to be reasonably accurate, with actual ridership at 8,500 average weekday boardings following one year of service (KCATA 2012).

\section{Las Vegas, Nevada}

Since opening the MAX BRT line along North Las Vegas Boulevard in 2004, RTC Transit has developed an extensive express bus network that extends across much of the city, with multiple lines that incorporate varying features of BRT service. Notable additions to the system include the launch of the Strip \& Downtown Express (SDX) service in 2010, the Boulder Highway Express service in 2011, and the Sahara Express service in 2012. Of these four lines, only the Sahara Express had reliable documentation of cost and ridership projections readily available for this analysis. 
The Sahara Express is a 12-mile BRT line that opened in May 2012 and features sheltered stops with raised-level boarding, dedicated bus lanes along most of the route, doubledecker buses, traffic signal priority, and landscaping improvements and widened sidewalks along the corridor. Projected capital costs were $\$ 43.56$ million (RTCSNV 2009), with actual capital costs at $\$ 45.2$ million. Projected ridership was 13,900 average daily boardings in 2013 (RTCSNV 2009). Actual ridership fell short of this projection, with only 10,000 average daily boardings in 2012 (Christensen 2012), with those figures remaining largely consistent through reported figures in April 2013 and April 2014 (RTCSNV 2014).

\section{Los Angeles, California}

The Orange Line is a BRT line operated by the Los Angeles County Metropolitan Transportation Authority, better known as Metro. An initial 14-mile segment opened in October 2005, with a 4-mile extension opening in June 2012. The Orange Line is regarded as one of the first "true" BRT systems in the US and uses a dedicated roadway along a former Southern Pacific Railroad branch line through the San Fernando Valley. The line features dedicated stations, pre-boarding fare payment, and a bikeway along the initial segment.

Projected capital costs were $\$ 340.4$ million for the initial segment (Metro 2003) and $\$ 135$ million for the extension (Guccione 2006; Callaghan and Vincent 2007). Actual capital costs were $\$ 323.6$ million for the initial segment, with an extra \$26 million for an additional station that opened in December 2006 (Callaghan and Vincent 2007) and \$154 million for the extension (Bloomekatz 2012).

Projected ridership was 5,000 to 7,500 average weekday boardings for the first year of service and 22,000 average weekday boardings by 2020 on the initial segment (Callaghan and Vincent 2007). Actual ridership far outpaced these projections, with 21,828 average weekday boardings in May 2006 (Callaghan and Vincent 2007), a figure that grew to nearly 24,000 average weekday boardings in October 2010 and 26,614 average weekday boardings in October 2011 (Hymon 2012). Prior to completion of the extension, Metro projected that the entire line including the extension would carry 45,000 daily riders by 2030 (Anderson 2012); whether this goal will be met remains to be seen, but average weekday Orange Line ridership rose from 26,670 in May 2012, one month prior to completion of the extension, to 31,780 in October $2013 .{ }^{5}$

\section{Minneapolis, Minnesota}

The METRO Red Line is an 11-mile BRT-lite service operated by Metro Transit. It opened in June 2013 and uses bus-only shoulder lanes between the Twin City suburbs of Bloomington and Apple Valley, with plans for a further extension south to the community of Lakeville.

The project was faced with construction setbacks, and the phasing of the project changed over time. The original plan was to implement the full Bloomington-Lakeville

\footnotetext{
${ }^{5}$ Information obtained through personal communication with D. Mieger, December 18, 2013.
} 
project in four phases with various elements of capital and operating investment in each phase. However, the most recent plan changed the investment strategy to three phases and altered the timing of the elements included in each stage. Operational costs for the system were cut back during construction, causing the initial roll-out of the system to be scaled back to a less-frequent service than originally planned. Projected capital costs under this revised plan were $\$ 118$ million, with the actual capital cost at $\$ 112$ million. ${ }^{6}$

Projected ridership was initially 2,250 average daily boardings, with a revised figure of 960 average daily boardings in the first year of service, following the reduction in service plans.7 Actual ridership was 975 average daily boardings in August 2014 (Van Berkel 2014), comparable to the revised figure but well below the initial projection.

\section{Pittsburgh, Pennsylvania}

The West Busway is a 5-mile dedicated busway used by the Port Authority of Allegheny County. Completed in 2000, the busway was originally planned to be 8.1 miles long and projected to cost $\$ 328.8$ million to build (FTA 2003). However, the estimate rose to $\$ 515$ million following issues with land acquisition from freight rail company CONRAIL and problems with the development of a proposed new HOV bridge over the Monongahela River into Downtown Pittsburgh. Ultimately, the CONRAIL land acquisition and proposed bridge elements were abandoned from the plan, and the project was scaled down from 8.1 miles to 5 miles, bringing the actual capital costs for the revised project down to $\$ 326.8$ million (FTA 2003), technically within the projected cost for the project but only after these significant changes to the proposal were made. Projected ridership for the busway was 7,000 riders per day (FTA 2003), with actual weekday ridership being more than 8,700 riders in October 2002 (FTA 2003) and growing to a peak daily ridership of 10,000 in 2004 (Vincent 2004) before leveling off in later years.

Another Port Authority of Allegheny County busway project in Pittsburgh was the East Busway Swissvale extension, a 2.3-mile extension of the East Busway that was completed in 2003. Projected capital costs for the extension were $\$ 62.8$ million (FTA 1998), with actual capital costs being $\$ 68.8$ million (Grata 2003). Projected ridership for the project was an additional 3,800 daily riders on the East Busway by 2005 (FTA 1998). Instead, there were only an additional 2,000 daily riders as of 2004 (Vincent 2004), with ridership falling since, dropping from an average of 30,000 daily riders in 2004 (Vincent 2004) to 25,600 in 2011 (Weinstock et al. 2011). The fall in ridership along the East Busway occurred at a time when annual ridership had fallen overall for the Port Authority of Allegheny County, dropping from 66 million passenger trips in 2001 to 63.8 million in 2011 (NTD 2002 and 2012).

\footnotetext{
${ }^{6}$ Information obtained through personal communication with C. Hiniker, December 17, 2013.

${ }^{7}$ Ibid.
} 


\section{Reno, Nevada}

The RTC RAPID is a 4.5-mile BRT-lite line operated by the Regional Transportation Commission of Washoe County (RTC). The service opened in Fall 2009, with additional phases completed in 2011 and 2013 that added more specialized BRT elements, and it currently features articulated buses, traffic signal priority, branded stations, floor-level boarding platforms, and off-board fare collection.

Projected capital costs for the system were $\$ 13.43$ million, with actual capital costs at $\$ 15.35$ million. ${ }^{8}$ Projected ridership for the line was $2,660,000$ boardings along the served corridor in FY 2010 and 3,079,283 boardings in FY 2013. Actual ridership fell short of these projections, with only 1,665,702 boardings along the served corridor in FY 2010 and 1,822,018 in FY 2013. ${ }^{9}$ Following the Great Recession, there was a systemwide reduction in ridership and service cuts, resulting in falling ridership along the corridor served by RTC RAPID in its opening years. Ridership along the corridor failed to reach FY 2007 levels (prior to introduction of the RTC RAPID) until FY 2012. Since introduction of the RTC RAPID service, ridership has grown by almost $10 \%$ in the corridor, a modest increase but still falling below early projections. ${ }^{10}$

\section{San Antonio, Texas}

VIA Primo is a 20-mile BRT-lite service operated by VIA Metropolitan Transit. Opened in December 2012, the service features branded stations and vehicles and a traffic signal priority system. Projected capital costs for the system were $\$ 40.1$ million, with actual capital costs being $\$ 35$ million. Projected ridership was 5,000 to 8,000 average daily riders following one year of service. Actual ridership fell within this range, with 5,800 average daily riders following one year of service. ${ }^{11}$

\section{San Bernardino, California}

The sbX Green Line is a 15.7-mile BRT line operated by Omnitrans. Opened for service in April 2014, the line features dedicated bus lanes for portions of the route, sheltered stations with platform-level boarding and ticket vending machines, and branded service.

Projected capital costs for the line were $\$ 191.7$ million (FTA 2010), which proved accurate judging from reports following completion (Starcic 2015). Projected ridership was 5,600 average daily boardings within opening year (FTA 2010). Actual ridership fell well short of this mark, with only 2,300 average daily boardings as of June 2015 (Wall 2015). Omnitrans officials have pointed to delays in the opening of a new transit center in Downtown San Bernardino, which originally was planned to open in tandem with the

\footnotetext{
${ }^{8}$ Information obtained through personal communication E. Park, January 27, 2014.

${ }^{9}$ Information obtained through personal communication R. Henson, February 26, 2014.

${ }^{10} \mathrm{lbid}$.

${ }^{11}$ Information obtained through personal communication with J. Aguilera, February 7, 2014.
} 
launch of the Green Line, as a factor in the line's low first year ridership (Wall 2015). The transit center finally opened in September 2015.

\section{San Diego, California}

The Mid-City Rapid, also branded the Rapid 215, is a 10-mile BRT-lite line operated by the Metropolitan Transit System (MTS). Service began in October 2014 and features dedicated travel lanes along a small portion of the route, distinctive sheltered stations, a traffic signal priority system, and specially-branded articulated buses.

Projected capital costs for the service were $\$ 43.3$ million (FTA 2008). Actual capital costs were $\$ 44$ million (SANDAG 2014). Projected ridership was initially 15,000 average daily boardings upon opening (FTA 2008), although this figure was revised to 7,000 to 9,000 average daily boardings before the opening of the project (Keatts 2014). Actual ridership seems to have fallen short of this mark, with only 6,500 average daily boardings as of June 2015 (Schaver 2015). More recent ridership data have not been made publicly available as of this writing; without figures from after a full year of service, ridership data have been excluded from the final analysis.

\section{Snohomish County, Washington}

Swift is a 16.7-mile BRT-lite service operated by Community Transit. Opened in November 2009, the service features seven miles of transit-only lanes, traffic signal priority, articulated buses, and branded stations with pre-boarding fare collection.

Projected capital costs were $\$ 15-20$ million (Community Transit 2005), with actual capital costs turning out to be $\$ 29$ million, with 4 stations included in the original plan deferred until 2011 due to funding issues (Community Transit 2011). Projected ridership was 2,500 average weekday boardings after one year of service and 4,000 average weekday boardings after four years of service (Duke 2010). Actual ridership exceeded these projections, with 3,500 average weekday boardings after one year of service (Duke 2010), and 4,400 average weekday boardings after four years of service (Munguia 2013). Swift ridership grew despite a system-wide reduction in ridership (Munguia 2010) and service cuts in 2010 and 2012, which reduced service frequency and operating hours for the BRT service (Munguia 2012). Annual ridership for Community Transit dropped from 11.4 million in 2009 to 9.1 million in 2012 (NTD 2010, 2013).

The following table summarizes the above case studies, comparing the predicted and actual costs in constant US dollars per mile and the predicted and actual ridership. 
TABLE 1. Summary of Individual Case Studies

\begin{tabular}{|c|c|c|c|c|c|c|c|c|c|c|}
\hline City & Project name & $\begin{array}{c}\text { System } \\
\text { type }\end{array}$ & $\begin{array}{c}\text { Year } \\
\text { opened }\end{array}$ & $\begin{array}{l}\text { Length } \\
\text { (in miles) }\end{array}$ & $\begin{array}{l}\text { Predicted } \\
\text { cost per mile } \\
\text { (in millions, } \\
\text { adjusted to } \\
2015 \text { values) }\end{array}$ & $\begin{array}{l}\text { Actual cost } \\
\text { per mile (in } \\
\text { millions, } \\
\text { adjusted to } \\
2015 \text { values) }\end{array}$ & $\begin{array}{c}\text { Actual total } \\
\text { cost as \% of } \\
\text { Predicted } \\
\text { total cost }\end{array}$ & Predicted ridership & Actual ridership & $\begin{array}{l}\text { Actual } \\
\text { ridership as } \\
\% \text { of } \\
\text { Predicted } \\
\text { ridership }\end{array}$ \\
\hline Cleveland & HealthLine & BRT & 2008 & 7.1 & $\$ 42.20$ & $\$ 30.43$ & $72 \%$ & $21,100 /$ day & $14,300 /$ day & $68 \%$ \\
\hline El Paso & BRIO Mesa Line & BRT-lite & 2014 & 8.6 & $\$ 3.17$ & $\$ 3.17$ & $100 \%$ & $11,900 /$ day & $2,000 /$ day & $17 \%$ \\
\hline \multirow[t]{2}{*}{ Escondido } & Breeze Rapid & BRT-lite & 2011 & 6 & $\$ 0.49$ & $\$ 0.73$ & $151 \%$ & & & \\
\hline & Emerald Express & BRT & 2007 & 4 & $\$ 7.00$ & $\$ 7.00$ & $100 \%$ & $\begin{array}{r}\text { Increase by } 40 \% \text { in } \\
20 \text { years }\end{array}$ & $\begin{array}{r}\text { Increase by } 222 \% \\
\text { in } 4 \text { years }\end{array}$ & $200+\%$ \\
\hline Eugene & & & & & & & & Additional & Additional & \\
\hline Eugene & Emerald Express Gateway Ext. & BRT & 2011 & 7.8 & $\$ 5.80$ & $\$ 5.56$ & $96 \%$ & $3,700 /$ day & $5,000 /$ day & $135 \%$ \\
\hline Fort Collins & MAX & BRT & 2014 & 5 & $\$ 16.48$ & $\$ 17.46$ & $106 \%$ & $3,900 /$ day & $4,680 /$ day & $120 \%$ \\
\hline Grand Rapids & Silver Line & BRT-lite & 2014 & 9.8 & $\$ 3.80$ & $\$ 4.10$ & $108 \%$ & $7,200 /$ day & $2,300 /$ day & $32 \%$ \\
\hline Kansas City & MAX Troost Line & BRT-lite & 2011 & 13 & $\$ 2.47$ & $\$ 2.46$ & $100 \%$ & $9,000 /$ day & $8,500 /$ day & $95 \%$ \\
\hline Las Vegas & Sahara Express & BRT-lite & 2012 & 12 & $\$ 3.77$ & $\$ 3.90$ & $103 \%$ & $13,900 /$ day & $10,000 /$ day & $72 \%$ \\
\hline Los Angeles & Orange Line & BRT & 2005 & 14 & $\$ 29.37$ & $\$ 27.92$ & $95 \%$ & $5,000-7,500 /$ day & $21,828 /$ day & $200+\%$ \\
\hline Los Angeles & Orange Line Canoga Ext. & BRT & 2012 & 4 & $\$ 34.69$ & $\$ 39.57$ & $114 \%$ & & & \\
\hline Minneapolis & METRO Red Line & BRT-lite & 2013 & 11 & $\$ 10.87$ & $\$ 10.31$ & $95 \%$ & $2,250 /$ day & 975/day & $43 \%$ \\
\hline \multirow[t]{2}{*}{ Pittsburgh } & West Busway & Busway & 2000 & 5 & $\$ 55.62^{*}$ & $\$ 89.57$ & $99 \%$ & $7,000 /$ day & $8,700 /$ day & $124 \%$ \\
\hline & & & & & & & & Additional & Additional & \\
\hline Pittsburgh & East Busway Ext. & Busway & 2003 & 2.3 & $\$ 35.01$ & $\$ 38.19$ & $109 \%$ & $3,800 /$ day & $2,000 /$ day & $53 \%$ \\
\hline Reno & RTC RAPID & BRT-lite & 2009 & 4.5 & $\$ 3.28$ & $\$ 3.75$ & $114 \%$ & $3.1 \mathrm{million} / \mathrm{yr}$ & $1.8 \mathrm{million} / \mathrm{yr}$ & $59 \%$ \\
\hline San Antonio & VIA Primo & BRT-lite & 2012 & 20 & $\$ 2.07$ & $\$ 1.80$ & $87 \%$ & $5,000-8,000 /$ day & $5,800 /$ day & $100 \%$ \\
\hline San Bernardino & sbX Green Line & BRT & 2014 & 15.7 & $\$ 12.27$ & $\$ 12.27$ & $100 \%$ & $5,600 /$ day & $2,300 /$ day & $41 \%$ \\
\hline San Diego & Mid-City Rapid & BRT-lite & 2014 & 10 & $\$ 4.35$ & $\$ 4.42$ & $102 \%$ & $15,000 /$ day & & \\
\hline \multirow{3}{*}{ Snohomish County } & Swift & BRT-lite & 2009 & 16.7 & $\$ 1.32$ & $\$ 1.91$ & $145 \%$ & 4,000/day & 4,400/day & $110 \%$ \\
\hline & earan & per mile & $\$ 5.08$ & 2 & di & er mile: & $\$ 12.13$ & & & \\
\hline & Median a & st per mile: & $\$ 5.56$ & & Average actual & cost per mile: & $\$ 16.03$ & & & \\
\hline
\end{tabular}

${ }^{*}$ Original West Busway proposal was an 8.1-mile project. 


\section{Results}

The BRT projects studied generally had more accurate cost estimates than the urban rail projects studied by Flyvbjerg. Of the 19 projects for which adequate cost information could be obtained, the actual capital costs of 10 came within $5 \%$ of their projected cost, and 16 came within $15 \%$ of their projected cost. However, although there was a high number of accurate or nearly accurate cost forecasts, the data also show a propensity towards projects coming in over their estimated budget, with 7 exceeding the projected cost by at least 5\%, compared to only 2 that underestimated it by at least 5\% (Figure 1). Of the projects described, the two that were far over budget (by at least $15 \%$ ) were BRTlite systems that had such low capital costs that even a difference of a few million dollars had a large proportional effect.

FIGURE 1.

Distribution of actual cost as percentage of predicted cost

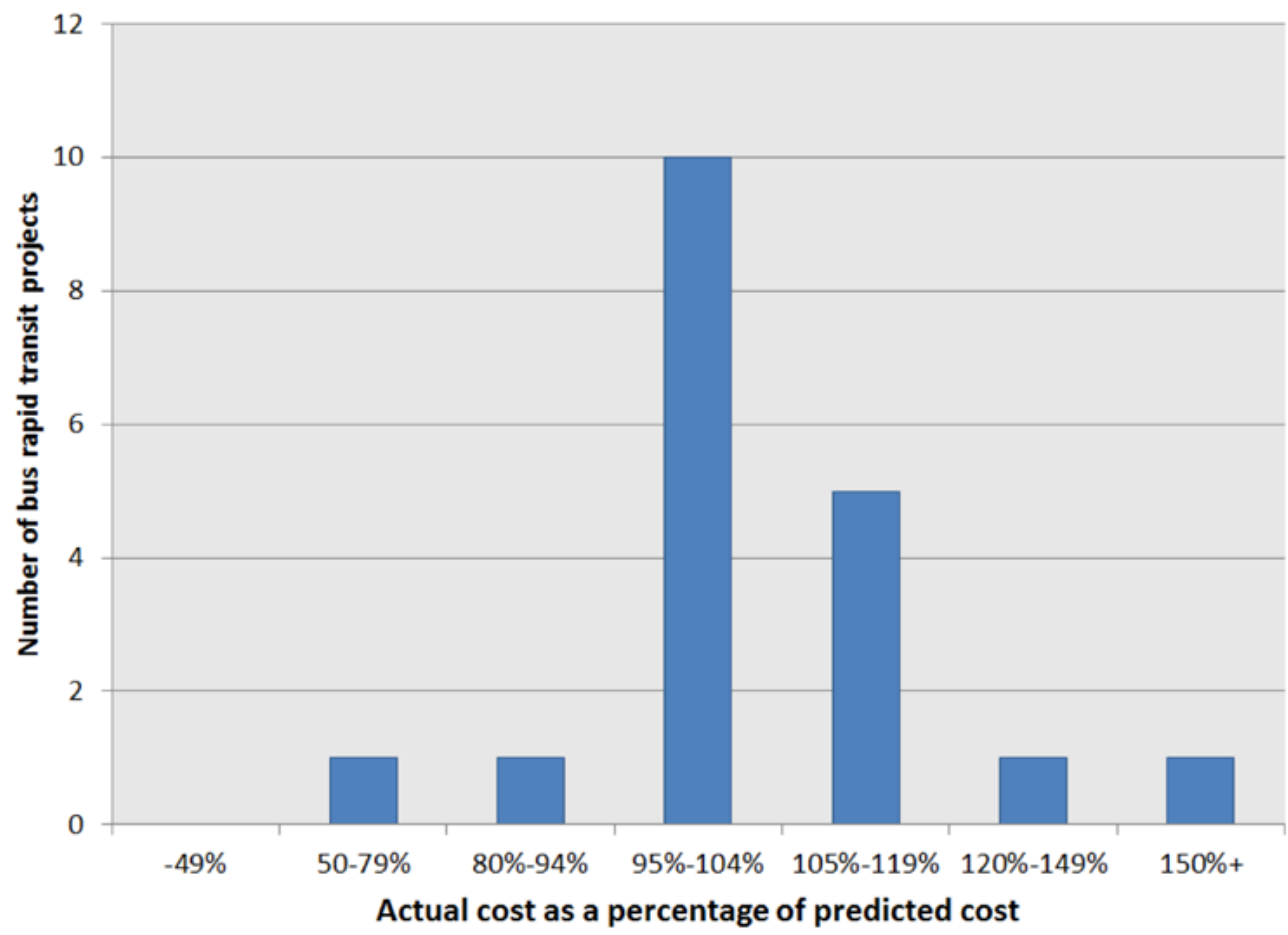

When it comes to ridership estimates, however, the overall picture is much different. Of the 16 projects for which adequate ridership data could be obtained, only 2 came within $10 \%$ of their projected ridership. The ridership projections also showed a propensity towards being over the actual ridership figures, with 8 projects seeing ridership at least $10 \%$ below what was projected versus only 6 seeing ridership at least $10 \%$ above the estimates (Figure 2). 
FIGURE 2.

Distribution of actual ridership as percentage of predicted ridership

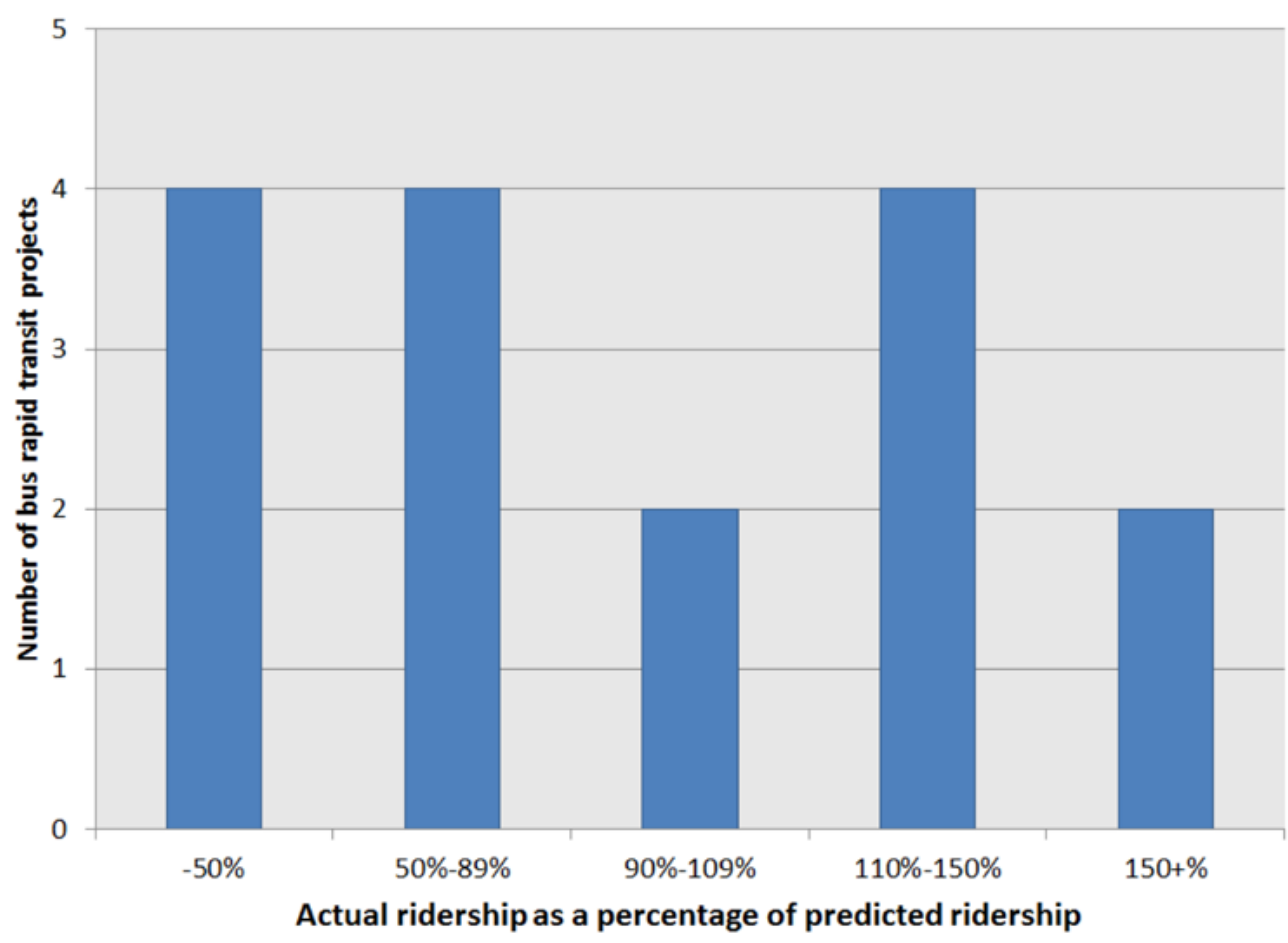

\section{Discussion}

Whereas there was a propensity towards projects coming in over budget among the systems studied, the level of accuracy shown suggests that BRT projects in the US do not suffer from the same level of cost estimate inaccuracies as the urban rail projects studied by Flyvbjerg or FTA. In general, the accuracy of the estimated costs for these systems was very good.

However, although there was a high level of accuracy in the cost estimates, it is worth noting that in a few cases these BRT projects came within budget only due to a scaling back of the project from what was initially proposed. This was particularly evident in the case of the Western Busway in Pittsburgh, where the scope of the project was significantly reduced, and to a lesser extent with the HealthLine in Cleveland, when the expense of certain design elements was scaled back.

The ridership estimates, on the other hand, not only showed a high level of inaccuracy but also a clear propensity towards predicting ridership higher than the actual results. This shows that current ridership forecasting methods still leave something to be desired and suggests that many US public transit agencies may be too optimistic as to the ridership outcomes of their BRT projects. In some cases, the underperformance of these projects has been attributed to outside factors; in San Bernardino, for instance, delays in the opening of a new transit center were blamed for their BRT system's low initial ridership.

A common theme among several of these projects was the effect of the Great Recession on ridership: in Cleveland, Minneapolis, Pittsburgh, and Reno, overall transit ridership 
dropped as a result of the recession and subsequent cuts to transit service, which likely was a factor in causing new BRT projects in these cities to fail to live up to ridership expectations. However, the recession cannot account for all of the underperforming systems included here; some of the newest systems studied, such as those in El Paso, Grand Rapids, and San Bernardino, performed below expectations despite the fact that their ridership estimates were generated well after the start of the Great Recession. Additionally, there is little to suggest that ridership forecasts have gotten more accurate over time (Figure 3).

FIGURE 3.

Accuracy of ridership forecasts by year

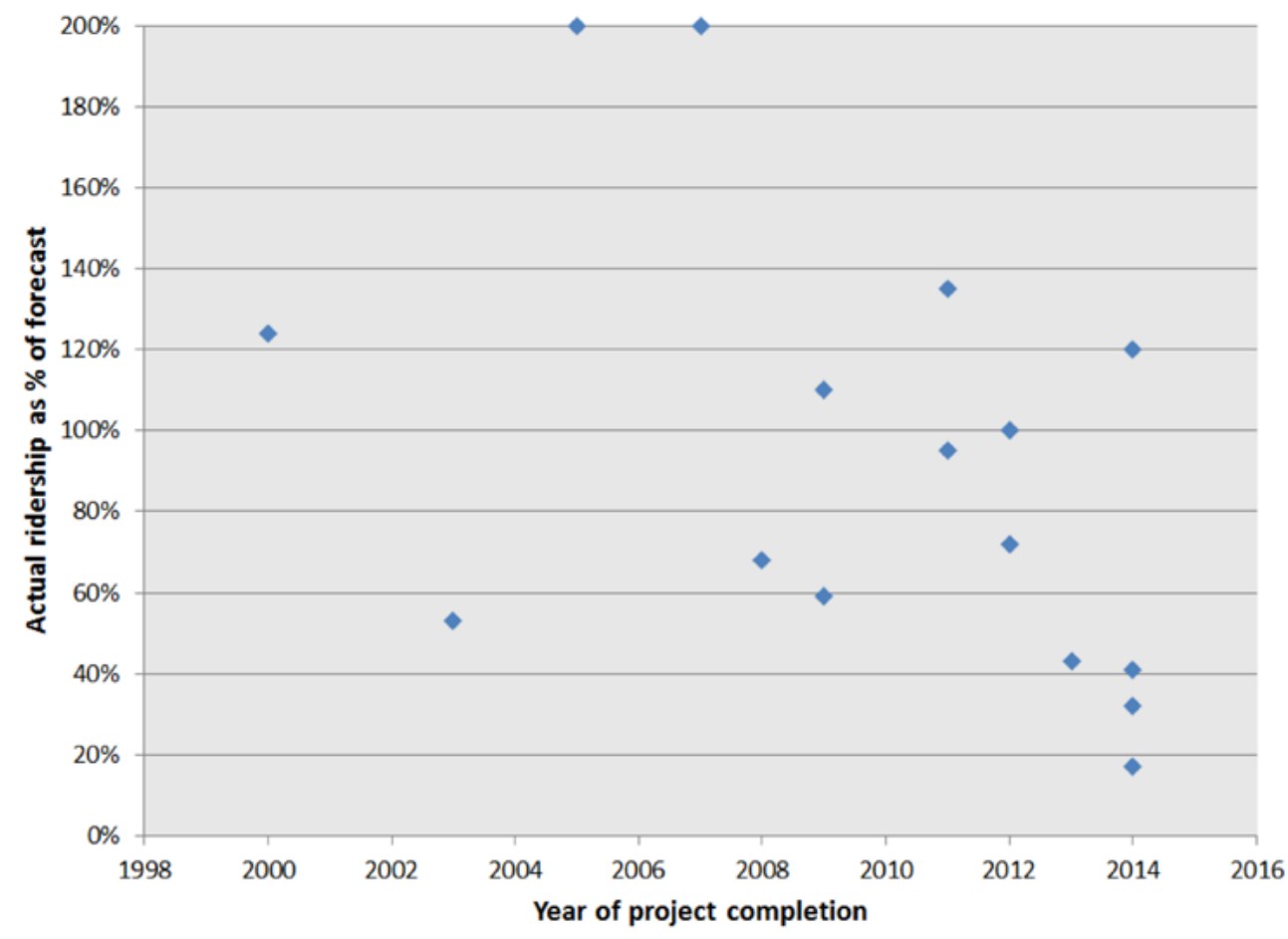

It is worth noting that ridership alone is not the only measure of success that can be applied to a public transportation infrastructure project, and, with few exceptions, the figures shown here reflect only the initial years of operating service. But transportation professionals should strive for a high degree of accuracy when discussing the potential benefits of a public transportation project, especially if they seek public confidence to expand public transportation infrastructure and service in the US in the years to come. It is not the intent of this research to question the worthiness of any of these BRT projects, but to note that a very common failing is occurring in the process of justifying these projects.

When applying for federal funding from FTA, three approaches can be taken to provide a ridership forecast: 1) using a region-wide travel model, 2) using incremental data-driven methods, which rely on existing ridership data and make projections by estimating the effects of proposed or expected changes, or 3) using FTA's Simplified Trips-on-Project Software (STOPS) created by FTA, a simplified version of the standard four-step travel model (FTA 2016). When creating ridership projections for future years, 
all three of these approaches rely on data input by local or regional agencies, including expected population and employment patterns. This brings us to a key weakness with standard travel forecasting methods: local governments and agencies in the US tend to be optimistic about future growth in population, employment, and transit ridership in their communities.

In his work, Flyvbjerg advocated for the adoption of "reference class forecasting," in which an outside view of a proposed project would be enforced by comparing it to the outcomes of a reference group of similar projects (Flyvbjerg et al. 2005). Although there are inherent difficulties in determining which projects serve as adequate reference points and compensating for the unique characteristics of any single project, such an approach would avoid many of the drawbacks of current standard approaches, in particular the tendency towards optimistic future growth forecasts. With a growing number of BRT projects in the US, there is a growing reference class of projects to use.

Flyvbjerg also pointed out that current funding mechanisms, in which transportation projects across the country compete against each other for crucial federal funding, create an incentive for local planners to oversell the benefits of their projects (Flyvbjerg et al. 2005). This could be addressed either by adopting different funding mechanisms, in which transportation projects do not have to compete directly against each other at the federal level, or by applying more rigorous scrutiny to ridership forecasts, perhaps by comparing them to similar projects as suggested above.

\section{Conclusions}

In recent years, BRT has become an increasingly-common option for local and regional agencies when investing in public transit infrastructure. The results of this analysis show that BRT projects in the US do very well when holding to their cost projections, but fall short where it comes to ridership projections. Although they skewed slightly towards being completed over budget, the cost estimates of the BRT projects studied tended to be far more accurate than the urban rail projects Flyvbjerg studied. But the widespread inaccuracy of the ridership estimates among the projects studied demonstrates that a more critical eye should be directed towards ridership projections. Although there is much inherent difficulty in accurately predicting future transit ridership, the tendency towards overestimating ridership shown here suggests a bias similar to that demonstrated by Flyvbjerg's research.

BRT offers an excellent opportunity for many communities to invest in high-quality public transportation. However, the results of this research suggest that there may be a tendency to oversell the benefits of these projects. With many new BRT projects under construction and opening in the years to come, it is important that transportation professionals apply more rigorous methodology to the ridership projections for these projects. 


\section{References}

Anderson, G. 2012. "Ready to Roll: Metro Orange Line Extension to Chatsworth." The Source. Los Angeles County Metropolitan Transportation Authority. http:// thesource.metro.net/2012/06/29/ready-to-roll-metro-orange-line-extension-tochatsworth/, accessed April 30, 2016.

Bain, R. 2009. "Error and Optimism Bias in Toll Road Traffic Forecasts." Transportation, 36(5). DOI: 10.1007/s11116-009-9199-7.

Bloomekatz, A. 2012. "Orange Line Bus Extension Goes Deeper into San Fernando Valley." Los Angeles Times, June 29. http://latimesblogs.latimes.com/lanow/2012/06/ orange-line-bus-extension-goes-deeper-into-san-fernando-valley.html, accessed April 30, 2016.

Callaghan, L., and W. Vincent. 2007. "Breakthrough Technologies Institute. A Preliminary Evaluation of the Metro Orange Line Bus Rapid Transit Project."

Christensen, N. 2012. "What's BRT? A Ride around Las Vegas on Its Bus Rapid Transit System." Oregon Metro News, December 5. http://www.oregonmetro.gov/news/ what-s-brt-a-ride-around-las-vegas-on-its-bus-rapid-transit-system, accessed April 30, 2016.

Community Transit. 2005. "Agency to Launch Region's First Bus Rapid Transit System." http://www.commtrans.org/newsrelease/1140, accessed April 30, 2016.

Community Transit. 2011. "Final Two Swift Stations Open Jan. 25." http://www. communitytransit.org/newsrelease/1431, accessed April 30, 2016.

de la Rosa, K. 2015. "Record Passenger Numbers Causes MAX Growing Pains." The Coloradoan, October 13. http://www.coloradoan.com/story/news/2015/10/12/ record-passenger-numbers-causes-max-growing-pains/73607708/, accessed April 30, 2016.

Duggan, K. 2014. “\$87 Million MAX Project Ready to Roll in Fort Collins." The Coloradoan, May 9. http://www.coloradoan.com/story/news/local/2014/05/08/ million-max-project-ready-roll-fort-collins/8883481/, accessed April 30, 2016.

Duggan, K. 2014. "MAX Ridership Dips with Start of Fare Service." The Coloradoan, October 2. http://www.usatoday.com/story/news/local/2014/10/01/max-ridershipdips-start-fare-service/16559815/, accessed April 30, 2016.

Duke, M. 2010. “October 2010 Swift Ridership." Seattle Transit Blog, November 30. http://seattletransitblog.com/2010/11/30/october-2010-swift-ridership/, accessed April 30, 2016.

Federal Transit Administration (FTA). 1998. "Martin Luther King Jr. East Busway Extension - Phase I." http://ntl.bts.gov/lib/7000/7600/7625/chapters/mlkbuswa. html, accessed April 30, 2016.

FTA. 2003. "Evaluation of Port Authority of Allegheny County's West Busway Rapid Transit Project." Report No. FTA-PA-26-7010-03.1. 
FTA. 2006-2016. "Before and After Studies of New Starts Projects." https://www.transit. dot.gov/funding/grant-programs/capital-investments/and-after-studies-new-startsprojects, accessed August 27, 2016.

FTA. 2007. "Troost Corridor BRT, Kansas City, Missouri.

FTA. 2008. "President's Spending Plan Recommends $\$ 1.62$ Billion for Transit Construction, Including New Projects in Nine Cities across the U.S." http://www. fcgov.com/mason/pdf/federaltransitadmin2-5-08.pdf, accessed April 30, 2016.

FTA. 2009. "Mason Corridor BRT, Fort Collins, Colorado."

FTA. 2009. "New Britain - Hartford Busway, Hartford, Connecticut."

FTA. 2010. “E Street Corridor sBX BRT, San Bernardino, California.”

FTA. 2010. "Mesa Corridor BRT, El Paso, Texas."

FTA. 2010. "Silver Line BRT, Grand Rapids, Michigan.”

FTA. 2012. "Federal Transit Administrator Rogoff Joins Nevada Officials for Opening of Sahara Express Bus Rapid Transit Service in Las Vegas." http://www.fta.dot.gov/ newsroom/news_releases/12286_14624.html, accessed April 30, 2016.

FTA. 2012. "Before and After Studies of New Starts Projects."

FTA. 2016. "Travel Forecasts." https://www.transit.dot.gov/funding/grant-programs/ capital-investments/travel-forecasts, accessed August 27, 2016.

Flyvbjerg, B., M. S. Holm, and S. L. Buhl. 2005. "How (In)accurate Are Demand Forecasts in Public Works Projects? The Case of Transportation." Journal of the American Planning Association, 71(2): 131-146. DOI: 10.1080/01944360508976688.

Freemark, Y. 2014. "Openings and Construction Starts Planned for 2014." The Transport Politic, January 5. http://www.thetransportpolitic.com/2014/01/05/openings-andconstruction-starts-planned-for-2014/, accessed April 30, 2016.

Grata, Joe, (2003). East Busway addition nearly completed. Pittsburgh Post-Gazette. June 7, 2003. http://old.post-gazette.com/transportation/20030607buswaytrans2p2.asp, accessed April 30, 2016)

Greater Cleveland Regional Transit Authority (GCRTA), (2012). Euclid Corridor Transportation Project - Bus Rapid Transit Before and After Study. July 2012.

Guccione, Jean (2006). MTA Will Run Orange Line Out to Chatsworth. Los Angeles Times. September 29, 2006. http://articles.latimes.com/2006/sep/29/local/ me-orangeline29, accessed April 30, 2016)

Hymon, Steve (2012). Ridership on Metro makes gains in October, new records on four lines. The Source. Los Angeles County Metropolitan Transportation Authority. November 12, 2012. http://thesource.metro.net/2012/11/14/ridership-on-metromakes-gains-in-october-new-records-on-four-lines/, accessed April 30, 2016.

Jarzab, J., J. Lightbody, and E. Maeda. 2002. "Characteristics of Bus Rapid Transit Projects: An Overview." Journal of Public Transportation, 5(2). DOI: http://dx.doi. org/10.5038/2375-0901.5.2.2. 
Kansas City Area Transportation Authority (KCATA). 2010. MAX Fact Sheet. http:// www.kcata.org/documents/uploads/MAX_Fact_Sheet.pdf, accessed April 30, 2016.

KCATA. 2012. "Kansas City's MAX Bus Rapid Transit System." Presentation to National Bus Rapid Transit Institute. http://www.nbrti.org/docs/ppt/Broward\%20County\%20 BRT\%20Workshop/Kansas_City_MAX.pdf, accessed April 30, 2016.

Keatts, A. 2014. “New Bus Line Distinction Under 'Rapid' Fire." Voice of San Diego. April 17. http://www.voiceofsandiego.org/bus-rapid-transit/new-bus-line-distinctionunder-rapid-fire/, accessed April 30, 2016.

Khut, J. 2016. "Grand Rapids Invests in first BRT in Michigan." Active Transportation Alliance, March 15. http://activetrans.org/blog/grand-rapids-invests-first-brtmichigan, accessed August 27, 2016.

Krietz, A. 2014. "As Silver Line Begins Rolling, Waiting Game for Potential Economic Boon Begins." MLive. August 25. http://www.mlive.com/news/grand-rapids/index. ssf/2014/08/silver_line_wheels_begins_roll.html, accessed April 30, 2016.

Levinson, H., S. Zimmerman, J. Clinger, and C. S. Rutherford. 2002. "Bus Rapid Transit: An Overview." Journal of Public Transportation, (5)2. DOI: http://dx.doi. org/10.5038/2375-0901.5.2.1.

Metro. 2003. "MTA Busway Coming to the Valley MTA Kicks Off Metro Rapid Transitway Project in San Fernando Valley." http://www.metro.net/news/simple_pr/ mta-busway-coming-valley-mta-kicks-metro-rapid-tra/, accessed April 30, 2016.

Munguia, M. 2010. "Swift, Vanpool Ridership Rise as Overall Ridership Falls." Community Transit Blog, March 17. http://communitytransit.blogspot.com/2010/03/swiftvanpool-ridership-rise-as-overall.html , accessed April 30, 2016.

Munguia, M. 2012. "Three Years Already? That's Swift!" Community Transit Blog, November 29. http://communitytransit.blogspot.com/2012/11/three-years-alreadythats-swift.html, accessed April 30, 2016.

Munguia, M. 2013. "Improvements Ahead as Swift Turns 4." Community Transit Blog, November 27. http://communitytransit.blogspot.com/2013/11/improvementsahead-as-swift-turns-4.html, accessed April 30, 2016.

National Transit Database (NTD). 2002, 2010, 2012, 2013. NTD Transit Profiles. http:// www.ntdprogram.gov/ntdprogram/profiles.htm, accessed April 30, 2016.

Polansky, R. 2015. "Busway Celebrates 1 Millionth Ride in West Hartford." WFSB Eyewitness News 3, September 9. http://www.wfsb.com/story/29989707/buswaycelebrates-1-millionth-ride-in-west-hartford, accessed April 30, 2016.

Regional Transportation Commission of Southern Nevada (RTCSNV). 2009. "Application for Supplemental Discretionary Grants for Capital Investments in Surface Transportation Infrastructure, Sahara Avenue Bus Rapid Transit Project." http:// www.rtcsnv.com/mpo/docs/TIGERapplication_Sahara\%20BRT_RTC\%20of\%20 Southern\%20Nevada_091009.pdf, accessed April 30, 2016. 
RTCSNV. 2014. "Monthly Operating Reports," July 30. http://www.rtcsnv.com/ wp-content/uploads/2012/06/07-30-14-taac-item-4-part-one.pdf, accessed April 30, 2016.

San Diego Association of Governments (SANDAG). 2014. “Mid-City Rapid/Rapid 215.” http://www.sandag.org/index.asp?projectid=317\&fuseaction=projects.detail, accessed April 30, 2016.

Schaver, Z. 2015. "Rapid Bus Isn't as Rapid as Everyone Hoped." Voice of San Diego, July 20. http://www.voiceofsandiego.org/topics/government/rapid-bus-isnt-as-rapid-aseveryone-hoped/, accessed April 30, 2016.

Starcic, J. 2015). “Omnitrans' sbX Green Line Service.” Metro Magazine, March 30. http:// www.metro-magazine.com/bus/article/293730/omnitrans-sbx-green-line-service, accessed April 30, 2016.

Sun Metro. 2014. “Brio." http://www.sunmetro.net/brio.html, accessed April 30, 2016.

Van Berkel, J. 2014. "A Slow but Instructive Start for South Metro's Red Line Busway." Minneapolis Star-Tribune. December 27. http://www.startribune.com/a-slow-butinstructive-start-for-south-metro-s-red-line-busway/286935741/, accessed April 30, 2016.

Vincent, B. 2004. "Breakthrough Technologies Institute. Bus Rapid Transit: The US Experience." http://www.reconnectingamerica.org/assets/Uploads/bestpractice206. pdf, accessed April 30, 2016.

Vuchic, V. 1992. "Urban Passenger Transportation Modes." In Public Transportation, Second Edition, (Gray and Hoel, eds.) Englewood Cliffs, NJ: Prentice-Hall.

Wall, S. 2015. "San Bernardino: Rapid Bus Line Off to Slow Start." The Press Enterprise. June 19. http://www.pe.com/articles/sbx-771011-san-bernardino.html, accessed April 30, 2016.

Weinstock, A., W. Hook, M. Replogle, and R. Cruz. 2011. "Recapturing Global Leadership in Bus Rapid Transit, A Survey of Select U.S. Cities."Institute for Transportation and Development Policy.

https://www.itdp.org/recapturing-global-leadership-in-bus-rapid-transit-a-survey-ofselect-u-s-cities/, accessed April 30, 2016.

Wilcox, K. 2016. "El Paso Extends Bus Rapid Transit." Civil Engineering. July 19. http://www.asce.org/magazine/20160719-el-paso-extends-bus-rapid-transit/, accessed August 27, 2016.

\section{About the Author}

John Perry (abqstreetcar@gmail.com) received an MA in City \& Regional Planning with a specialization in Transportation Planning from the University of North Carolina at Chapel Hill in 2014 and a BA in Environmental Planning and Design with an emphasis in Community Planning from the University of New Mexico in 2012. While 
in Albuquerque, he discovered a passion for urban and transportation planning, with a particular interest in public transit and active transportation systems. He has worked as an advocate for the improvement of sustainable transportation in the US. He currently lives in Ames, lowa. 